\title{
PENGARUH LIGAN PADA SINTESIS SENYAWA KOMPLEKS CO(II) DENGAN LIGAN BASA SCHIFF N,N-DIMETIL-4- (FENILIMINOMETIL)ANILIN DAN 1,10-FENANTROLIN
}

\author{
Zipora Sembiring ${ }^{1 *}$, Syaiful Bahri ${ }^{1}$, Rinawati ${ }^{1}$, Adita Sukma Ramadhania ${ }^{1}$, Aura Dhayang \\ Fiarizky $^{1}$ \\ ${ }^{1}$ Jurusan Kimia FMIPA Universitas Lampung, Bandar Lampung
}

zipora.sembiring@fmipa.unila.ac.id

\begin{tabular}{|l|}
\hline Artikel Info \\
Diterima \\
tanggal \\
12.09 .2021 \\
Disetujui \\
publikasi \\
tanggal \\
20.10 .2021 \\
\\
Kata kunci : \\
basa Schiff, \\
kompleks, \\
senyawa \\
kompleks \\
Co(II), N,N- \\
Dimetil-4- \\
(feniliminomet \\
il)anilin 1,10- \\
fenantrolin \\
\hline
\end{tabular}

\begin{abstract}
ABSTRAK
Telah dilakukan sintesis senyawa kompleks Co(II) dengan ligan basa Schiff N,N-Dimetil-4-(feniliminometil)anilin dan ligan 1,10-Fenantrolin. Sintesis senyawa kompleks dilakukan dengan reaksi kondensasi refluks pada suhu $78{ }^{\circ} \mathrm{C}$ menggunaan pelarut etanol, menghasilkan kristal berwarna coklat muda dengan rendemen sebesar 68\% untuk kompleks Co(II) basa Schiff dan berwarna oranye dengan rendemen sebesar $72,60 \%$ untuk kompleks $\mathrm{Co}$ (II) Fenantrolin. Kristal yang diproleh kemudian dikarakterisasi menggunakan spektrofotometer UV-Vis, FTIR, dan TG-DTA. Berdasarkan hasil karakterisasi menunjukkan terbentuknya kompleks Co(II) basa Schiff dan kompleks Co(II) Fenantrolin. Kemudian untuk melihat pengaruh ligan pada pembentukan senyawa kompleks dilakukan karakterisasi menggunakan MSB dan dihasilkan momen magnet efektif $\left(\mu_{\text {eff }}\right)$ senyawa kompleks Co(II) basa Schiff sebesar 3,87 BM yang bersifat paramagnetik, sedangkan pada kompleks Co(II) Fenantrolin memiliki momen magnet efektif $\left(\mu_{\text {eff }}\right)$ sebesar 4,72 BM yang bersifat paramagnetik serta membentuk agen khelat. Hasil karakterisasi menggunakan MSB menunjukkan kompleks Co(II) Fenantrolin memiliki kestabilan yang lebih baik dibandingan dengan ligan basa Schiff N,N-Dimetil-4(feniliminometil)anilin.
\end{abstract}

\section{ABSTRACT}

Synthesis of the complex compound Co(II) with the basic ligand Schiff N,N-Dimethyl-4(phenyliminomethyl)aniline and the ligand 1,10-Phenanthroline has been carried out. The synthesis of complex compounds was carried out by reflux condensation reaction at a temperature of $78{ }^{\circ} \mathrm{C}$ using ethanol as a solvent, producing light brown crystals with a yield of $68 \%$ for the Schiff base $\operatorname{Co}$ (II) complex and orange with a yield of $72.60 \%$ for the Co(II) Phenanthroline complex. The crystals obtained were then characterized using UV-Vis spectrophotometer, FTIR, and TG-DTA. Based on the results of the characterization showed the formation of a Schiff base Co(II) complex and a $\mathrm{Co}$ (II) Phenanthroline complex. To see the effect of ligands on the formation of complex compounds, characterization was carried out using MSB and resulting an effective magnetic moment ( $\mu$ eff) for the Schiff base $\mathrm{Co}$ (II) complex compound was $3.87 \mathrm{BM}$ which was paramagnetic, while the $\mathrm{Co}(\mathrm{II})$ Phenanthroline complex had an effective magnetic moment ( $\mu$ eff) of $4.72 \mathrm{BM}$ which is diamagnetic and forms a chelate. The results of characterization using MSB showed that the Phenanthroline Co(II) complex had better stability than the Schiff base ligand N,N-Dimethyl-4-(phenyliminomethyl)aniline.

http://dx.doi.org/10.23960/aec.v6.i2.2021.p180-188

Anal.Environ.Chem. 


\section{PENDAHULUAN}

Senyawa kompleks menjadi hal yang menarik untuk diteliti karena memiliki aplikasi dalam berbagai bidang, seperti bidang kesehatan, bidang pertanian, dan bidang industri. Senyawa kompleks terbentuk karena adanya ikatan antara ligan yang berperan sebagai donor pasangan elektron dengan atom pusat atau logam yang berperan sebagai akseptor pasangan elektron (Triyani dkk., 2013). Logam transisi merupakan logam yang banyak dipelajari dan disintesis menjadi senyawa-senyawa kompleks yang menghasilkan warna yang unik (David and Raynor, 1965). Salah satu logam yang sering digunakan pada sintesis senyawa kompleks adalah kobalt, dikarenakan logam kobalt merupakan logam golongan transisi yang bersifat inert dan stabil untuk membentuk senyawa kompleks dengan berbagai ligan (Rodgers, 2002).

Contoh ligan yang dapat digunakan dalam pembentukan senyawa kompleks adalah ligan 1,10 fenantrolin (fen). Fen dapat berfungsi sebagai ligan bidentat, hal ini disebabkan ligan fen merupakan ligan $\mathrm{N}$ - heterosiklik yang mempunyai dua atom donor $\mathrm{N}$ yang terikat pada cincin aromatis yang dapat meningkatkan kestabilan senyawa kompleks (Sharma dan Narula, 2015). Garai, dkk (2017) telah mensintesis kompleks [Co(fen $)_{2} \mathrm{Cl}_{2}$ ] dari ion logam $\mathrm{Co}^{2+}$ dari kompleks $\mathrm{CoCl}_{2} \cdot 6 \mathrm{H}_{2} \mathrm{O}$ dengan ligan 1,10-fenantrolin menggunakan metode refluks selama 3 jam dan menghasilkan rendemen $71 \%$. Pada penelitian ini akan disintesis senyawa kompleks $\mathrm{Co}(\mathrm{II})$ Fenantrolin dari kompleks $\mathrm{CoCl}_{2} \cdot 6 \mathrm{H}_{2} \mathrm{O}$ dengan ligan 1,10-fenantrolin mengunakan metode refluks. Selain fen, ligan yang dapat digunakan dalam pembentukan senyawa kompleks adalah ligan basa Schiff.

Ligan basa Schiff merupakan produk hasil kondensasi antara amina primer dengan senyawa aldehid atau keton. Ligan basa Schiff memiliki gugus imina atau disebut juga gugus azometina (-C=N-) (Imer et al., 2017). Gugus azometina pada basa Schiff memiliki banyak kelebihan salah satunya dapat membentuk cincin khelat dalam senyawa kompleks sehingga ketika berikatan dengan ion logam akan membentuk struktur kompleks dan memiliki kestabilan yang cukup baik (Sembiring, 2017). Sari (2019) telah mensintesis ligan basa Schiff dari senyawa 4-dimetilaminobenzaldehida sebagai aldehid dengan anilin sebagai amina primer menggunakan kondensasi refluks selama 45 menit menghasilkan rendemen 76,20\%. Abduljleel et al., (2018) juga telah mensintesis ligan basa Schiff dari senyawa vanilin dan propana-1, 3-diamin dengan ion logam $\mathrm{Co}^{2+}$ menggunakan kondensasi refluks menghasilkan 
senyawa kompleks dengan rendemen sebesar $68 \%$. Pada penelitian ini juga akan dilakukan sintesis senyawa kompleks dari ion logam $\mathrm{Co}^{2+}$ dengan ligan basa schiff N,N-dimetil-4(fenilaminometil)anilin menggunakan kondensasi refluks.

Kristal yang diperoleh dikarakterisasi menggunakan spektrofotometer UltravioletVisible (UV-Vis), Fourier Transform Infra Red (FTIR), Differential Thermal AnalysisThermogravimetric Analysis (DTA-TGA), dan Magnetic Susceptibility Balance (MSB) untuk mengetahui pengaruh ligan pada pembentukan senyawa kompleks. Senyawa kompleks dengan ligan 1,10- fenantrolin akan membentuk struktur geometri oktahedral dengan tiga agen khelat, sehingga diharapkan memiliki tingkat kestabilan yang lebih tinggi dibandingkan senyawa kompleks Co(II) basa Schiff yang memiliki struktur geometri tetrahedral. Karakterisasi yang dilakukan pada senyawa kompleks dapat menunjukkan karakteristik sifat fisik dan dan kimia senyawa kompleks untuk diaplikasikan dalam berbagai bidang.

\section{METODE}

\section{Alat dan Bahan}

Alat utama yang digunakan dalam penelitian ini adalah kaca arloji, pipet volume 2 $\mathrm{mL}$, gelas kimia $100 \mathrm{~mL}$, gelas ukur $25 \mathrm{~mL}$, labu ukur $10 \mathrm{~mL}$, pipet tetes merk Iwaki dan Pyrex, corong gelas, satu set peralatan refluks (boiling $50 \mathrm{~mL}$ Pyrex flatt, kondensor, statif , clamp holder dan boshed $2 \mathrm{pcs}$ ), termometer $100^{\circ} \mathrm{C}$, batang pengaduk, desikator, spatula, furnace, neraca analitik merek Kern dan Son GMBH ABT 220-4M, magnetic, hot plate, instrumen spektrofotometer UV-Vis, spektrofotometer FTIR, DTA-TGA, dan MSB.

Bahan utama yang digunakan dalam penelitian ini adalah N,N-Dimetil-4(feniliminometil)anilin, 1,10-fenantrolin p.a Merck, etanol p.a Merck, akuabides, $\mathrm{CoCl}_{2} \cdot 6 \mathrm{H}_{2} \mathrm{O}$, kertas saring whattman 42 , dan aluminium foil.

\section{Prosedur}

Sintesis senyawa kompleks dari ion logam $\mathrm{Co}^{2+}$ dengan ligan basa Schiff N,NDimetil-4- (feniliminometil)anilin dan 1,10-Fenantrolin dilakukan dengan mencampur masing-masing ligan basa Schiff N,N-Dimetil-4-(feniliminometil)anilin dan 1,10-Fenantrolin dengan ion logam $\mathrm{Co}^{2+}$ dari $\mathrm{CoCl}_{2} \cdot 6 \mathrm{H}_{2} \mathrm{O}$. Kemudian campuran direfluks selama 2 jam pada suhu $78{ }^{\circ} \mathrm{C}$ dengan pelarut etanol sambil diaduk menggunakan pengaduk magnetik, kemudian disaring. Campuran yang terbentuk dicuci dengan akuabidest untuk mendapatkan 
kompleks yang murni. Kristal kemudian dikeringkan dalam desikator, ditimbang hingga mencapai berat konstan, dan dikarakterisasi dengan spektrofotometer UV-Vis, spektrofotometer FTIR, DT-TGA, dan MSB.

\section{HASIL DAN PEMBAHASAN}

\section{Sintesis senyawa kompleks Co(II) dengan ligan basa Schiff N,N-}

Dimetil-4- (feniliminometil)anilin dan 1,10-Fenantrolin.

Sintesis ion logam $\mathrm{Co}^{2+}$ dari $\mathrm{CoCl}_{2} \cdot 6 \mathrm{H}_{2} \mathrm{O}$ dengan ligan basa Schiff N,N-Dimetil-4(feniliminometil)anilin dan 1,10-Fenantrolin bertujuan untuk membentuk senyawa kompleks. Senyawa kompleks Co(II) dengan ligan basa Schiff N,N-Dimetil-4-(feniliminometil)anilin yang diperoleh dalam penelitian ini berupa padatan kristalin berwarna coklat muda sebanyak 0, 4204 gram dengan rendemen 68, 48\%. Sintesis senyawa kompleks Co(II) dengan ligan 1,10Fenantrolin menghasilkan padatan kristalin berwarna oranye sebanyak 0,552 gram dengan rendemen $72,6 \%$. Kristal hasil sintesis dapat dilihat pada gambat 1 :

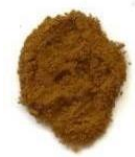

(a)

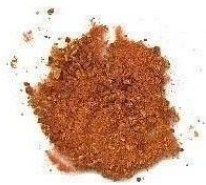

(b)

Gambar 1. Kristal Senyawa Kompleks Co(II) basa Schiff (a) dan Senyawa Kompleks Co(II) Fenantrolin (b)

\section{Karakterisasi Spekrofotometer UV-Vis}

Karakterisasi panjang gelombang maksimum dilakukan pada senyawa kompleks Co(II) basa Schiff dan Co(II) 1,10-Fenantrolin hasil sintesis menggunakan spektrofotometer UV-Vis pada panjang gelombang 200-600 nm. Hasil spektrum ditunjukkan melalui gambar 2:

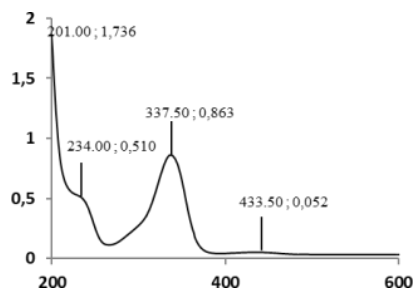

(a)

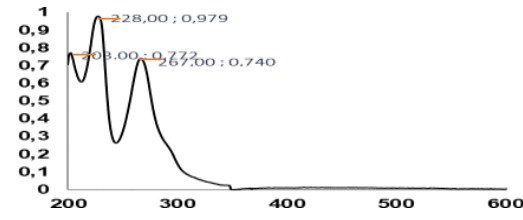

(b)

Gambar 2. Spektrum UV-Vis kompleks Co(II) Basa Schiff (a) dan kompleks Co(II) Fenantrolin (b) 
Karakterisasi menggunakan spektrofotometer UV-Vis diperoleh panjang gelombang maksimum untuk ligan basa Schiff dan fenantrolin adalah sebesar 337,5 nm dan $265 \mathrm{~nm}$, sedangkan panjang gelombang maksimum untuk senyawa kompleks Co(II) basa Schiff dan senyawa kompleks Co(II) fen adalah sebesar 433,5 nm dan $267 \mathrm{~nm}$. Hal tersebut membuktikan bahwa kompleks Co(II) basa Schiff dan kompleks Co(II) Fenanrolin telah terbentuk karena terjadi pergeseran panjang gelombang dari ligan ke senyawa kompleks hasil sintesis.

\section{Karakterisasi Spekrofotometer FTIR}

Karakterisasi menggunakan FTIR bertujuan untuk menentukan gugus fungsi khas dari kompleks Co(II) basa Schiff dan Co(II) Fenanrolin hasil sintesis. Karakterisasi dilakukan pada bilangan gelombang $4000-400 \mathrm{~cm}^{-1}$.

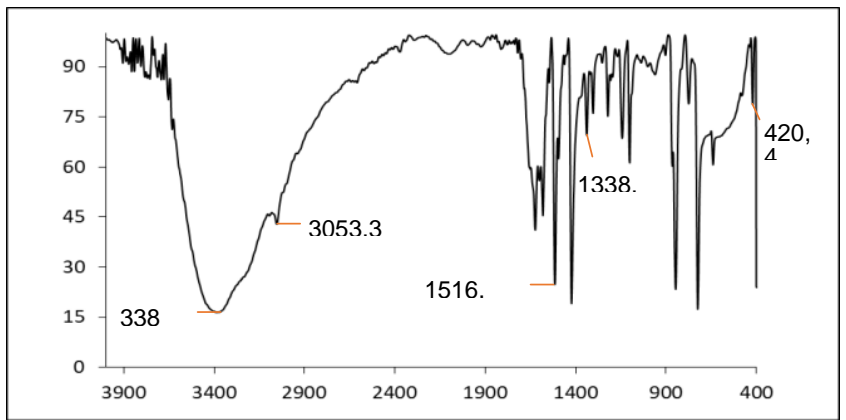

\section{Gambar 3. Spektrum FTIR Kompleks Co(II) basa Schiff}

Puncak serapan kompleks Co(II) basa Schiff (Co-N) (Gambar 3) terlihat pada daerah serapan bilangan gelombang $518 \mathrm{~cm}^{-1}$ yang menunjukkan bahwa kompleks Co(II) telah terbentuk dan telah berhasil disintesis. Penelitian Tufa et al., (2018) menunjukkan bahwa kompleks Co(II) dengan ligan basa Schiff dari senyawa vanilin dan anilina terbentuk pada daerah bilangan gelombang $492 \mathrm{~cm}^{-1}$. Hal ini sesuai dengan teori yang menyatakan bahwa gugus (M-N) muncul pada bilangan gelombang 400-600 $\mathrm{cm}^{-1}$ (Khopkar, 1990). 


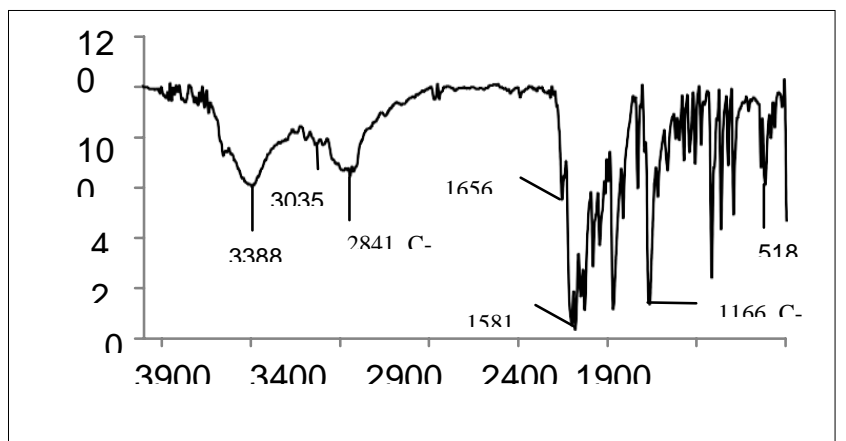

\section{Gambar 4. Spektrum FT-IR Kompleks Co(II) Fen}

Puncak serapan kompleks Co(II) Fenantrolin (Co-N) (Gambar 4) terlihat pada daerah serapan bilangan gelombang 420, $48 \mathrm{~cm}^{-1}$. Ikatan Co-N pada senyawa hasil sintesis muncul pada bilangan gelombang 420,48 $\mathrm{cm}^{-1}$, serupa dengan serapan Co-N yang terdapat didaerah $418,57 \mathrm{~cm}^{-1}$ pada penelitian Putri, A (2016). Hal tersebut menunjukkan bahwa logam Co telah berikatan dengan atom $\mathrm{N}$ pada ligan 1,10- Fenantrolin.

\section{Karakterisasi Differential Thermal Analysis-Thermogravimetric (DTA-TGA)}

Tabel 1. Hasil analisis DT-TGA senyawa kompleks Co(II) basa Schiff dan senyawa kompleks Co(II) fenantrolin

\begin{tabular}{ccccl}
\hline \multicolumn{1}{c}{ Sampel } & Suhu ${ }^{\circ} \mathbf{C}$ & Material & TGA \% & \\
\cline { 4 - 5 } & & & Analisis & Teori \\
\hline $\begin{array}{l}\text { Senyawa Kompleks Co(II) } \\
\text { basa Schiff }\end{array}$ & $59,79-97$ & $\mathrm{CH}_{3} \mathrm{CH}_{2} \mathrm{OH}$ & 3,96 & 6,97 \\
& $202,54-247$ & $\left(\mathrm{C}_{15} \mathrm{H}_{16} \mathrm{~N}_{2}\right)_{2}$ & 64,37 & 67,88 \\
& $287,5-500$ & $\mathrm{Cl}_{2}$ & 12,79 & 10,75 \\
& & & & 5,45 \\
$\begin{array}{c}\left.\text { [Co(fen) })_{3}\right] \mathrm{Cl}_{2} .5 \mathrm{H}_{2} \mathrm{O} \\
\begin{array}{c}\text { Senyawa kompleks Co(II) } \\
\text { fenantrolin }\end{array}\end{array}$ & $50-100$ & $\left.5 \mathrm{H}_{2} \mathrm{O}\right)_{2} \mathrm{O}$ & 12,11 & 11,2 \\
& & & & \\
& $105-253$ & $\mathrm{C}_{8} \mathrm{H}_{12} \mathrm{~N}_{2}$ & 20,71 & 23,7 \\
& $254-405$ & $\mathrm{C}_{8} \mathrm{H}_{12} \mathrm{~N}_{2}$ & 24,67 & 23,7 \\
\hline
\end{tabular}

Karakterisasi menggunakan DTA-TGA bertujuan untuk menentukan sifat termal dari kompleks Co(II) basa Schiff dan kompleks Co(II) Fenantrolin. Karakterisasi ini dilakukan pada suhu $50-500^{\circ} \mathrm{C}$ dengan kenaikan temperatur $5^{\circ} \mathrm{C} / \mathrm{menit}$. Data hasil analisis 
dari DTA-TGA juga dapat digunakan untuk menentukan formula senyawa kompleks Co(II) yang terbentuk dengan menghitung persen kehilangan berat dari masing-masing molekul kemudian membandingkannya dengan perhitungan hasil secara teoritis.

Pada Tabel 1 dapat dilihat data hasil \% perhitungan pengurangan massa secara analisis dan teoritis dari kompleks Co(II) basa Schiff dan kompleks Co(II) Fenantrolin menunjukkan kompleks Co(II) basa Schiff telah mengalami dekomposisi tiga tahap. Dekomposisi pertama yaitu pada suhu sekitar 59,79- $97^{\circ} \mathrm{C}$. Pada suhu ini, terjadi perubahan massa sebesar 3,96 \% setara dengan lepasnya satu molekul etanol $\left(\mathrm{CH}_{3} \mathrm{CH}_{2} \mathrm{OH}\right)$. Dekomposisi kedua yaitu pada suhu sekitar 202,54- $247^{\circ} \mathrm{C}$. Pada suhu ini terjadi perubahan massa yang drastis sebesar 64,37\% setara dengan lepasnya dua molekul ligan basa Schiff $\left(\mathrm{C}_{15} \mathrm{H}_{16} \mathrm{~N}_{2}\right)$. Dekomposisi ketiga yaitu pada suhu sekitar $287,5-500{ }^{\circ} \mathrm{C}$ dimana terjadi perubahan massa sebesar $12,79 \%$ setara dengan lepasnya dua molekul ligan $\mathrm{H}_{2} \mathrm{O}$ dan satu molekul $\mathrm{Cl}_{2}$. Pada suhu diatas $500{ }^{\circ} \mathrm{C}$ merupakan sisa $\%$ massa dari logam kobalt. Berdasarkan hasil karakterisasi menggunakan DTA-TGA, kompleks Co(II) basa Schiff memiliki formula yaitu $\left[\mathrm{Co}\left(\mathrm{C}_{15} \mathrm{H}_{16} \mathrm{~N}_{2}\right)_{2}\left(\mathrm{H}_{2} \mathrm{O}\right)_{2}\right] \mathrm{Cl}_{2}$.

Pada kompleks Co(II) Fenantrolin proses dekomposisi massa senyawa hasil sintesis terbagi menjadi 3 tahap. Tahap pertama, terjadi pengurangan massa pada rentang suhu 50$123^{\circ} \mathrm{C}$ sebanyak $12,11 \%$ yang merupakan empat molekul $\mathrm{H}_{2} \mathrm{O}$ yang berasal dari ion logam $\mathrm{CoCl}_{2} \cdot 6 \mathrm{H}_{2} \mathrm{O}$. Tahap kedua, pada rentang suhu $120-405^{\circ} \mathrm{C}$ terjadi dekomposisi massa secara bertahap sebanyak 20,71\% dan 24,67\%, dekomposisi tersebut merupakan dekomposisi dari dua molekul ligan fenantrolin yang digunakan. Persen massa yang tersisa sebesar 42,51\% merupakan tahap terakhir dekomposisi massa kompleks Co(II) Fenantrolin yang terdiri dari 1 molekul ligan fen sebanyak 25,67\%, dekomposisi gugus $\mathrm{Cl}_{2}$ sebanyak 6,98\%, dan dekomposisi kobalt oksida $(\mathrm{CoO})$ sebanyak 9,86\%. Berdasarkan persen massa kehilangan setiap unsur pada data hasil analisis, prediksi rumus senyawa kompleks Co(II) Fenantrolin yang dihasilkan adalah $\left[\mathrm{Co}(\mathrm{fen})_{3}\right] \mathrm{Cl}_{2} .5 \mathrm{H}_{2} \mathrm{O}$.

\section{Karakterisasi Magnetic Susceptibility Balance (MSB)}

Hasil karakterisasi dengan MSB, senyawa kompleks Co(II) basa Schiff memiliki momen magnet sebesar 3,87 BM dengan bentuk geometri tetrahedral. Ligan basa Schiff merupakan ligan lemah sehingga senyawa kompleks memiliki 5 elektron tidak berpasangan

http://dx.doi.org/10.23960/aec.v6.i2.2021.p180-188

Anal.Environ.Chem. 
(spin tinggi) dan bersifat diamagnetik.

Senyawa kompleks Co(II) fenantrolin memiliki momen magnet sebesar 4,720 BM dengan bentuk geometri oktahedral disertai dengan terbentuknya tiga agen khelat yang dapat menstabilkan struktur senyawa kompleks. Ligan Fenantrolin merupakan ligan kuat sehingga senyawa kompleks bersifat paramagnetik.

\section{KESIMPULAN}

Senyawa kompleks Co(II) dari hasil sintesis dengan ligan basa Schiff dan juga 1,10Fenantrolin menghasilkan warna kristal, rendemen, momen magnet, bentuk geometri, dan kestabilan yang berbeda. Pada kompleks Co(II) basa Schiff menghasilkan kristal berwarna coklat dengan rendemen $68 \%$, sedangkan pada kompleks Co(II) Fenantrolin menghasilkan kristal berwarna kuning dengan rendemen 72,60\%. Berdasarkan hasil karakterisasi menggunakan spektrofotometer UV-Vis, FTIR, dan DTA-TGA menunjukkan kompleks Co(II) basa Schiff dan kompleks Co(II) Fenantrolin terbentuk. Hasil karakterisasi menggunakan MSB menunjukkan kompleks Co(II) Fenantrolin memiliki kestabilan yang lebih baik dibandingan dengan ligan basa Schiff, karena kompleks Co(II) Fenantrolin memiliki momen magnet efektif $\left(\mu_{\text {eff }}\right)$ sebesar 4,72 BM yang bersifat paramagnetik dan membentuk tiga agen khelat.

\section{UCAPAN TERIMA KASIH}

Terima kasih yang sebesar-besarnya kepada tim penelitian senyawa kompleks, Laboratorium Anorganik/Fisik Jurusan Kimia FMIPA Universitas Lampung, serta semua pihak yang turut membantu.

\section{DAFTAR PUSTAKA}

Abduljleel, A. M., Alshawi, J., and Abbood, M. N. 2018. Synthesis , Characterization And Biological Studies of Schiff Bases Derived From Vanillin And Their Complexes With Cobalt ( II ). Journal Of Chemical, Biological and Physical Sciences. Vol. 8. No. 2. Pp. 135-153.

David, M.A and J.B. Raynor. 1965. Advanced Practical Inorganic Chemistry. Jhon Wiley \& Sons. London. 
Garai, M., Dey. D., Ram, H. Y., Maji, M., Roy, A. C, and Biswas, B. (2017). Synthesis and phosphatase activity of a Cobalt(II) phenanthroline. Journal Chemistry Science.Vol. 6. Pp.11040-11047.

Imer, A. G., Syan, R. H. B., Gulcan, M., Ocak, Y.S., and Tombak, A. 2017. The Novel Pyridine Based Symmetrical Schiff Base Ligand And Its Transition Metal Complexes: Synthesis, Spectral Definitions And Application In Dye Sensitized Solar Cells (DSSCs). Journal Mater Science : Mater Electron.

Khopkar, S. M. 1990. Konsep Dasar Kimia Analitik. Universitas Indonesia Press. Jakarta.

Triyani, N. F., Suhartana, dan Sriatun. 2013. Sintesis dan Karakterisasi KompleksNi(II)- EDTA dan Ni(II)- Sulfanilamid. Chem Info. Vol. 1. No. 1. Pp. 354-361.

Putri, A. N. (2016). Sintesis dan Uji Toksisitas Kompleks Kobalt(II) dengan Ligan (6E)- N2-((E)- 2-(6Aminopiridin-2-Ilimino)-1,2-Difeniletilidin)Piridin-2,6-Diamina- Skripsi. Surabaya: Institut Teknologi Surabaya.

Rodgers, G.E. (2002). Descriptive Inorganic, Coordination, and Solite-State Chemistry, 2nd Edition. Canada: Thomson Learning.

Sari, P. N. 2019. Sintesis Dan Karakterisasi Senyawa Basa Schiff Dari (4- Dimetilaminobenzaldehida Dan Anilina) Sebagai Dyesensitizer Pada Dye Sensitized Solar Cell (DSSC) Menggunakan Variasi Elektrolit Gel (Skripsi). Universitas Lampung. Lampung.

Sembiring, Z. 2017. Sintesis dan Karakteristik Struktur Senyawa Kompleks Cu(II) dan Mn(II) dengan basa Schiff Turunan Aldehida Sebagai Indikator. Seminar Nasional DIPA-FMIPA 2017, 1-41.

Sharma, G., dan Narula, A. K. (2015). Synthesis of Eu(II) Complexes with 2-Aminopyridine and 1,10Phenantroline: Structural, Optical, Termal and Morphological Studies. Sensors and Actuators. Sensors and Actuators B Chemical, Vol. 215. Pp. 584-591.Tufa, A., Endale, M., and Desalegn, T. 2018. Synthesis, Characterization and Antibacterial Activity Of Copper(II) and Cobalt(II) VanillinAniline SchiffBase Complex. Chemistry and Materials Research. Vol. 10. Pp. 38-45. 